\title{
Protocol: analytical methods for visualizing the indolic precursor network leading to auxin biosynthesis
}

\author{
Molly Tillmann ${ }^{*}{ }^{\circledR}$, Qian Tang ${ }^{\dagger}$ and Jerry D. Cohen
}

\begin{abstract}
Background: The plant hormone auxin plays a central role in regulation of plant growth and response to environmental stimuli. Multiple pathways have been proposed for biosynthesis of indole-3-acetic acid (IAA), the primary auxin in a number of plant species. However, utilization of these different pathways under various environmental conditions and developmental time points remains largely unknown.

Results: Monitoring incorporation of stable isotopes from labeled precursors into proposed intermediates provides a method to trace pathway utilization and characterize new biosynthetic routes to auxin. These techniques can be aided by addition of chemical inhibitors to target specific steps or entire pathways of auxin synthesis.

Conclusions: Here we describe techniques for pathway analysis in Arabidopsis thaliana seedlings using multiple stable isotope-labeled precursors and chemical inhibitors coupled with highly sensitive liquid chromatography-mass spectrometry (LC-MS) methods. These methods should prove to be useful to researchers studying routes of IAA biosynthesis in vivo in a variety of plant tissues.
\end{abstract}

Keywords: Auxin biosynthesis, Stable isotope labeling, LC-MS, Metabolic inhibitors, Pathway analysis

\section{Background}

Plant life is characterized by strictly regulated developmental events that achieve optimum growth and reproduction. This is accomplished through an extremely complex hormonal signaling network in which the plant growth hormone auxin plays a central and defining role. To this end, auxin helps regulate almost all aspects of plant growth and development including embryogenesis, tissue architecture and tropic responses [1]. Maintenance of auxin homeostasis involves multiple pathways for the biosynthesis of indole-3-acetic acid (IAA), the principal auxin in plants, and several regulatory pathways as well as subsequent catabolic events. These additional input/

*Correspondence: mkreiser@umn.edu

†Molly Tillmann and Qian Tang contributed equally

Department of Horticultural Science and Microbial and Plant Genomics

Institute, University of Minnesota, St. Paul, MN, USA output processes include conjugation and hydrolysis of sugar and cyclitol conjugates, amino acid, peptide and protein conjugates, formation and $\beta$-oxidation of indole3 -butyric acid as well as deactivation by ring oxidation of IAA and its amino acid conjugates [2, 3]. Nevertheless, how much IAA is made and accumulates remains the critical regulatory event in many aspects of plant development [4].

Although several biosynthetic pathways for the bioactive auxin IAA have been proposed, many of them have not been well defined and flux information is largely lacking (Fig. 1). The predominant biosynthetic route to IAA in Arabidopsis thaliana is widely believed to be through the YUCCA pathway, in which the amino acid tryptophan (Trp) is converted to indole-3-pyruvic acid (IPyA), which is then converted to IAA by YUCCA flavin monooxygenase enzymes [5]. Species-specific evidence for the synthesis of IAA from Trp through indole-3-acetaldoxime 


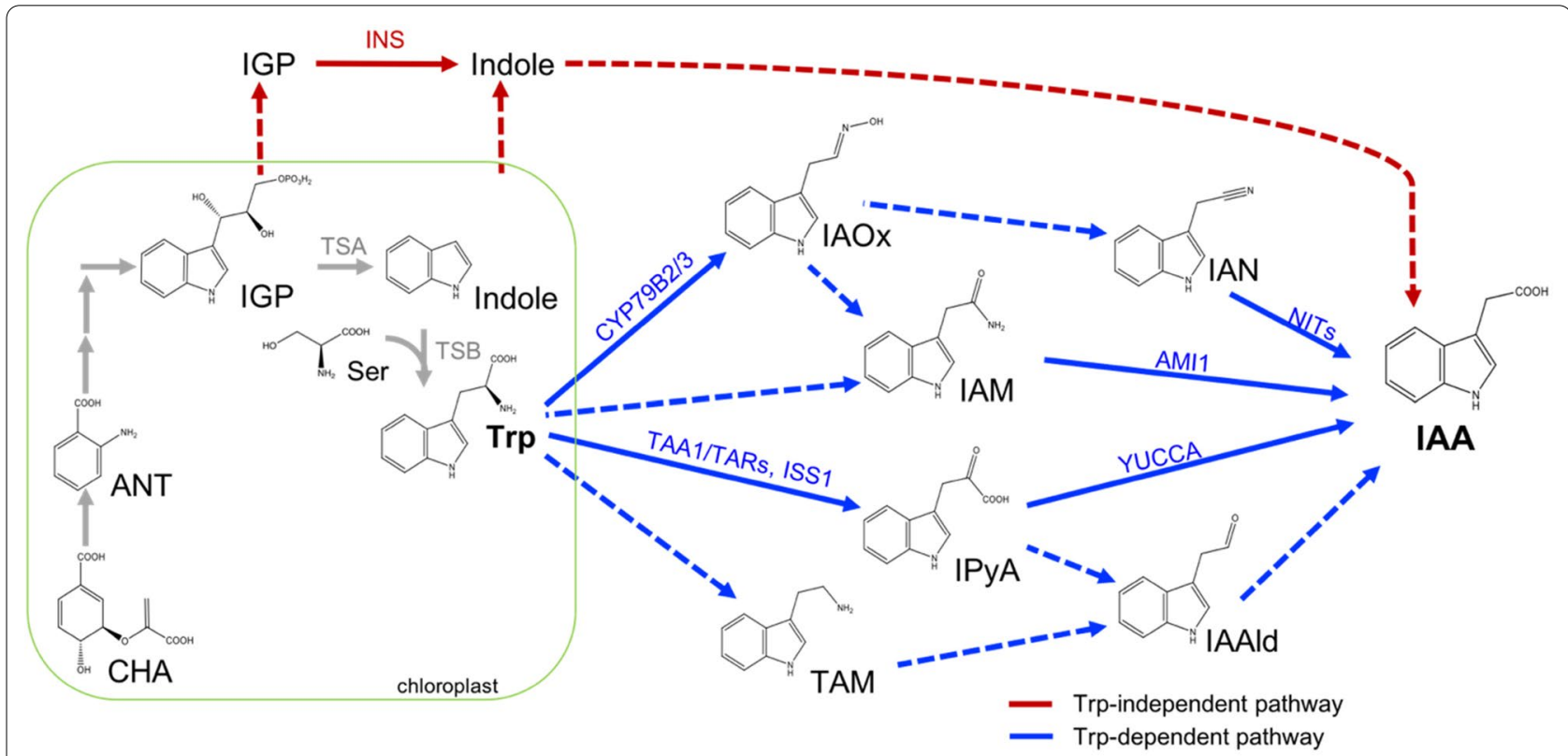

Fig. 1 Major pathways for IAA biosynthesis. Solid arrows refer to pathways with enzymes identified in at least one species, and dashed arrows to undefined ones. AMI1, indole-3-acetamide hydrolase-1; ANT, anthranilate; CHA, chorismic acid; IAAld, indole-3-acetaldehyde; CYP79B2/3, cytochrome P450 (79B2/3); IAM, indole-3-acetamide; IAN, indole-3-acetonitrile; IAOx, indole-3-acetaldoxime; IGP, indole-3-glycerol phosphate; INS, indole synthase; IPyA, indole-3-pyruvic acid; ISS1, Indole Severe Sensitive 1; NIT, nitrilase; Ser, serine; TAA1, tryptophan aminotransferase of Arabidopsis 1; TAR, tryptophan aminotransferase-related; TAM, tryptamine; Trp, tryptophan; TSA, tryptophan synthase a; TSB, tryptophan synthase $\beta$; YUCCA, Arabidopsis flavin monooxygenase

(IAOx), which is converted to indole-3-acetamide (IAM) and sometimes an indole-3-acetonitrile (IAN) intermediate has been shown in Arabidopsis [6, 7]. Other potential intermediates of IAA synthesis downstream of Trp have been proposed, such as indole-3-acetaldehyde (IAAld) [8-10] and tryptamine (TAM) [11], though their places within the web of auxin biosynthesis have not been well detailed. A Trp-independent route has also been proposed based on tryptophan synthase mutants, metabolic flux analysis and in vitro analyses, in which indole or another upstream compound serves as the IAA precursor [1, 12-14]; however, unbound chemical intermediates, if they are involved in this pathway, have as yet not been identified [15]. The purpose of this protocol is to describe improved techniques for characterization of the auxin metabolic network utilizing recently discovered chemical inhibitors and technical advances in mass spectrometry (Fig. 2). These tools will allow researchers to characterize auxin biosynthesis during specific developmental events or environmental responses.

Metabolic inhibitor approaches are complementary to genetic and biochemical studies and are particularly useful in studying IAA biosynthesis. While auxin biosynthesis mutants may have severe developmental defects that alter growth and confound comparisons to wild type plants [16], biosynthetic reactions can be turned off at specific developmental time points with chemical inhibitors. Additionally, genetic redundancy can be overcome by inhibiting an entire enzyme family with a single chemical treatment [17]. Such is the case with inhibitors targeting both steps in the YUCCA pathway. The YUCCA enzymes are encoded by multiple genes in Arabidopsis thaliana and mutations in small sets of these genes encoding the flavin monooxygenase proteins results in significant morphological defects [18]. A number of chemical inhibitors have been developed to inhibit the YUCCA pathway of auxin biosynthesis (Table 1), providing valuable tools to study the function of this pathway in different plant tissues and environmental conditions. Similarly, TAA1/TAR/ISS1/VAS1 (Tryptophan Aminotransferase of Arabidopsis 1/ Tryptophan Aminotransferase Related/ Indole Severe Sensitive 1 and reversal of sav3 phenotype 1) form a set of enzymes with overlapping biochemical functions that catalyze the penultimate step in the IPyA pathway [19]. Alternative aromatic amino acid substrates, such as L-kynurenine, can act as competitive inhibitors of tryptophan aminotransferase and a series of potent inhibitors have been developed to pyridoxal phosphate-dependent enzymes with enhanced specificity to TAA1 and related enzymes ("pyruvamines"; see Table 1) [20]. 


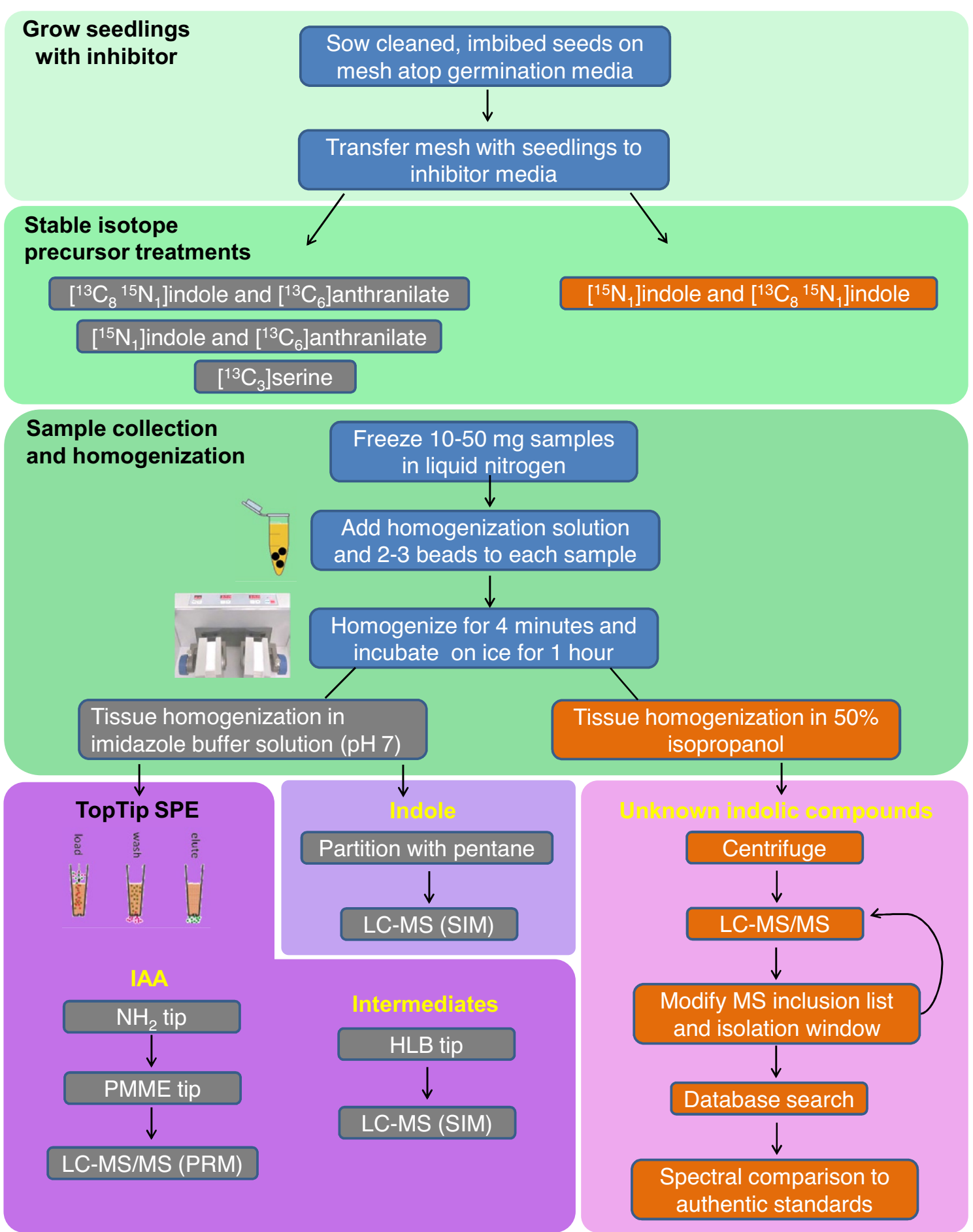

Fig. 2 Workflow summary for labeling and analysis of the auxin metabolic network. Various labeling and analysis techniques are used to investigate different aspects of auxin biosynthesis. For absolute quantitation, internal standards are added to samples prior to homogenization

The issues of redundancy with tryptophan synthase (TS) are a bit different. Arabidopsis and maize have two copies of the genes that encode each of the two proteins that form the $\alpha \beta \beta \alpha$ heterodimeric complex that catalyzes the formation of tryptophan from indole-glycerolphosphate and serine in the plastids. In addition, maize 
Table 1 Some chemical inhibitors of auxin biosynthesis

\begin{tabular}{|c|c|c|c|c|}
\hline Inhibitor name & Representative structure(s) & Target & Mode of action & Reference \\
\hline BBo & $\begin{array}{l}\text { 3-chlorophenylboronic acid, } \\
\text { 4-biphenylboronic acid }\end{array}$ & YUCCA & Competitive inhibitor & {$[50]$} \\
\hline PPBo & 4-phenoxyphenyl-boronic acid & YUCCA & Competitive inhibitor & {$[50]$} \\
\hline Ponalrestat & $\begin{array}{l}\text { 2-(3-(4-Bromo-2-fluorobenzyl)- } \\
\text { 4-oxo-3,4-dihydrophthalazin- } \\
\text { 1-yl)acetic acid }\end{array}$ & YUCCA & Substrate antagonist & [51] \\
\hline Yucasin & $\begin{array}{l}\text { 5-(4-chlorophenyl)-4H-1,2,4- } \\
\text { triazole-3-thione }\end{array}$ & YUCCA & Competitive inhibitor & {$[52]$} \\
\hline Yucasin DF (YDF) & $\begin{array}{l}\text { 5-[2,6-difluorophenyl]-2,4-dihy- } \\
\text { dro-[1,2,4]triazole-3-thione }\end{array}$ & YUCCA & Competitive inhibitor & [53] \\
\hline $\begin{array}{l}\text { Pyruvamines (PVM) "Type I } \\
\text { compounds" }\end{array}$ & $\begin{array}{l}\text { PVM1169; L-alpha-(aminooxy)- } \\
\text { 3-(naphthalen-2-yl)propanoic } \\
\text { acid }\end{array}$ & TAA1 & Competitive inhibitor & {$[20]$} \\
\hline $\begin{array}{l}\text { Pyruvamines (PVM) "Type II com- } \\
\text { pounds" (Derivatives of Type I } \\
\text { compounds) }\end{array}$ & $\begin{array}{l}\text { PVM2153; Benzene propanoic } \\
\text { acid, 3,4-dichloro-a-[(1,3- } \\
\text { dihydro-1,3-dioxo- } 2 \text { H-isoindol- } \\
\text { 2-yl)oxy]-, methyl ester }\end{array}$ & TAA1 & Competitive inhibitor & {$[20]$} \\
\hline L-Kynurenine (Kyn) & $\begin{array}{l}\text { (2S)-2-Amino-4-(2-aminophenyl)- } \\
\text { 4-oxobutanoic acid }\end{array}$ & TAA1 & $\begin{array}{l}\text { Alternative substrate/ Competi- } \\
\text { tive inhibitor }\end{array}$ & [54] \\
\hline AVG & Aminoethoxyvinyl-glycine & TAA1 & Slow-binding inhibition & {$[55]$} \\
\hline AOPP & $\begin{array}{l}\text { L-aminooxyphenyl-propionic } \\
\text { acid }\end{array}$ & TAA1 & Competitive inhibitor & {$[55]$} \\
\hline $\mathrm{AOA}$ & Amino-oxyacetic acid & TAA1 & & {$[55]$} \\
\hline AOIBA & 2-amino-oxyisobutyric acid & TAA1 & & [55] \\
\hline Indoleacrylic acid & trans-indole-3-acrylic acid & Trp synthase $\beta$ and a & Allosteric inhibitor & {$[56,57]$} \\
\hline (1-Fluorovinyl)glycine & a-(1'-fluoro)vinyl glycine & Trp synthase $\beta$ & $\begin{array}{l}\text { PLP-enzyme mechanism-based } \\
\text { inhibitor }\end{array}$ & {$[58]$} \\
\hline Arylsulfide phosphonates & $\begin{array}{l}\text { [4-[(2-aminophenyl) sulfanyl] } \\
\text { butyl] phosphonic acid }\end{array}$ & Trp synthase a & Transition state analog & {$[59,60]$} \\
\hline Indoline-5-sulfonamides & $\begin{array}{l}\text { 1-(2-Fluorobenzoyl)-N-methyl- } \\
\text { 5-indoline sulfonamide } \\
\text { N-Methyl-1-[(5-methyl-2- } \\
\text { thienyl)carbonyl]-5-indolinesul- } \\
\text { fonamide }\end{array}$ & $\begin{array}{l}\text { Trp synthase inter- subunit } \\
\text { interface }\end{array}$ & Allosteric inhibitor & {$[61]$} \\
\hline $\begin{array}{l}\text { Sulfolane and indole-5-sulfon- } \\
\text { amide }\end{array}$ & $\begin{array}{l}\text { GSK1, (3R,4R)-4-[4-(2-chlo- } \\
\text { rophenyl)piperazin-1-yl]- } \\
\text { 1,1-dioxothiolan- 3-ol); GSK2, } \\
\text { (1-[2-fluorobenzoyl]-N- } \\
\text { methyl-2,- } \\
\text { 3-dihydro-1H-indole-5-sulfon- } \\
\text { amide) }\end{array}$ & $\begin{array}{l}\text { Trp synthase inter- subunit } \\
\text { interface }\end{array}$ & Allosteric inhibitor & {$[62]$} \\
\hline Aryl sulfonamides & $\begin{array}{l}\text { [F9]; N-(4'-Trifluoromethoxy } \\
\text { benzenesulfonyl)-2-aminoethyl } \\
\text { Phosphate }\end{array}$ & Trp synthase $\beta$ & a-Site allosteric ligand & {$[63]$} \\
\hline Benzamide & $\begin{array}{l}\text { N-(4-Carbamoyl benzyl)-5-(3- } \\
\text { chloro phenyl)-1,2-oxazole- } \\
\text { 3-carboxamide }\end{array}$ & Trp synthase a & a-Site ligand & [64] \\
\hline
\end{tabular}

has genes BX1 and IGL for TS $\alpha$-like cytosolic enzymes that serve as sources of free indole [21]. Arabidopsis also has a cytosolic TS $\alpha$-like enzyme encoded by the indole synthase (INS) gene [22]. TS is, however, a well-researched and highly conserved bi-enzyme complex [23] such that inhibitors are available (Table 1) that target specifically TS $\alpha$, TS $\beta$ as well as the $25-\AA$ long tunnel to the $\beta$-subunit where indole diffuses in order to participate in the TS $\beta$ pyridoxal 5'-phosphatemediated $\beta$-addition reaction with serine. Determining the possibility of a tryptophan-independent pathway is largely dependent on having Trp auxotroph mutants, which are difficult to obtain due to redundancy of Trp synthase genes and the fact that mutations in both copies of TS $\beta$ are seedling lethal $[12,13,24]$. The protocols described here largely overcome these issues by 
employing chemical inhibitors, and can complement genetic studies.

Mass spectrometry (MS) has historically been and continues to be an important technique in deciphering routes of auxin biosynthesis, enabling accurate quantitation of IAA and its precursors, identification of intermediates, and tracking of isotopic labels through distinct pathways. Quantitative methods for IAA and precursor analysis by MS have been invaluable tools in elucidating auxin biosynthesis pathways and have continuously evolved over time with advances in analytical sensitivity and resolution [4, 25-29]. Stable isotope tracing experiments also lend insight into auxin biosynthesis when plant tissue is supplied with one or more labeled precursors, such as indole and/or anthranilate [30-32], and label incorporation into suspected downstream intermediates is monitored to determine whether synthesis from the labeled precursor has occurred. This approach can also provide information regarding direction of flow and flux through different steps [6]. Additionally, labeled precursors that are unique to one pathway in particular can be applied to measure contributions of a specific pathway to the IAA pool $[5,33]$.

\section{Results and discussion}

In this paper, we describe methods utilizing metabolic inhibitors coupled with a modified approach of isotope dilution/tracing and using liquid chromatography-high resolution-mass spectrometry (LC-HR-MS) for qualitative and quantitative analysis of a comprehensive set of IAA precursors and IAA itself to characterize auxin biosynthesis in Arabidopsis (see Additional file 1). A distinct advantage of this method is its ability to resolve potential precursor compounds by chromatographic retention, absolute mass and by elemental composition, enabling complex mixtures of different stable isotopes (for example, multiple labeled compounds with ${ }^{13} \mathrm{C}$ and ${ }^{15} \mathrm{~N}$ can be resolved) to be used in the experimental procedures (see Additional file 2). Readers may also consult a complementary paper that was published while this manuscript was in preparation [34]. Growing seedlings on fully ${ }^{15} \mathrm{~N}$-labeled media as described here enables accurate quantitation of biosynthetic intermediates by reverse isotope dilution, using unlabeled internal standards which are typically more readily available than isotopically labeled standards [35]. The addition of one or more ${ }^{15} \mathrm{~N}$ atoms at a mass addition of 0.9970 can be resolved from the more abundant natural occurrence of ${ }^{13} \mathrm{C}$, which is 0.0034 heavier than ${ }^{12} \mathrm{C}$, which improves the utility of this approach when using high resolution analysis. Seedlings are first germinated on nylon mesh and are easily transferred onto media containing chemical treatments at the desired developmental time point.
Next, stable isotope-labeled precursor compounds are fed to the plant. Labeled serine is used as a tracer for Trpdependent biosynthesis specifically [33], while labeled indole and anthranilate can feed into both Trp-dependent and Trp-independent pathways [19, 31, 32] (Fig. 1). The techniques described here offer several advantages over previously described methods in their ease of preparation, high level of sensitivity, capacity for monitoring many compounds at once (see Additional file 2), and the ability of high resolution analysis to distinguish between different 'heavy' atoms, as might be required with $\left[{ }^{13} \mathrm{C}_{1}\right]$ IAA and $\left[{ }^{15} \mathrm{~N}_{1}\right]$ IAA labeling products. As shown in Additional file 1, the use of multiple labels makes it easy to see that the addition of the tryptophan monooxygenase inhibitor YDF increases the incorporation of labeled indole into IAA but decreases labeling from labeled anthranilate and to a lesser degree from labeled tryptophan. Furthermore, this IAA labeling pattern for labeled indole and anthranilate is not reflected in any of the proposed intermediates following YDF treatment.

We also describe a technique for identifying novel intermediates based on the characteristic quinolinium ion produced from MS fragmentation of 3-substituted indolic compounds. This method involves using a series of injections of the same sample with increasingly narrow mass ranges, similar to the methods utilized by $\mathrm{Yu}$ et al. [36] and Tang et al. [37] where they targeted and identified novel indolic compounds. By monitoring exact masses of $\left[{ }^{13} \mathrm{C}_{8},{ }^{15} \mathrm{~N}_{1}\right]$ - and $\left[{ }^{15} \mathrm{~N}_{1}\right]$ quinolinium ions after treatment with $\left[{ }^{13} \mathrm{C}_{8},{ }^{15} \mathrm{~N}_{1}\right]$ - and $\left[{ }^{15} \mathrm{~N}_{1}\right]$ indole, this method can identify unknown compounds synthesized downstream from indole. A similar approach would likely be applicable in investigations of other classes of compounds that form characteristic signature ions. High resolution accurate mass analysis significantly reduces factors such as false negative molecular ions, low abundance ions, multiple isomers, and matrix effects, which otherwise would make it difficult to confirm possible compound identities.

\section{Materials and methods \\ Materials \\ Growing, labeling, and collecting plant material}

Wild-type Columbia-0 ecotype Arabidopsis thaliana seeds or specific metabolic mutant lines need to be surface sterilized sodium hypochlorite then imbibed for $5-10$ days at $4{ }^{\circ} \mathrm{C}$ to promote uniform germination. Typically seeds would be sown in a single row onto $20 \mu \mathrm{m}$ nylon mesh covering the agar growth medium.

- $20 \mu \mathrm{m}$ nylon mesh (Sefar, 03-20/14), cut into $9 \mathrm{~cm}$ $\times 9 \mathrm{~cm}$ squares and autoclave sterilized with $45 \mathrm{~min}$ sterilization time at $121{ }^{\circ} \mathrm{C}$ 
- Sterile deionized water

- Forceps, flame sterilized

- $10 \mathrm{~cm} \times 10 \mathrm{~cm}$ square Petri dishes (Fisherbrand, FB0875711A)

- Dilute bleach solution for seed sterilization: $20 \mathrm{~mL}$ concentrated regular liquid bleach (Clorox), $80 \mathrm{~mL}$ deionized water, $20 \mu \mathrm{L}$ Tween 80 (Sigma-Aldrich, P1754)

- Plant growth medium: Arabidopsis thaliana salts (ATS) [38]

- KimWipes delicate task wipes (Kimberly-Clark, KC34155EXL)

- $1.5 \mathrm{~mL}$ microcentrifuge tubes (Fisherbrand, 05-408129)

- Liquid nitrogen

- Dry ice

- One or more isotopically labeled precursor solutions in aqueous ATS salts (see Notes 1 and 2; see Table 2 for description of example labeling strategies):

- $3 \mathrm{mM}\left[{ }^{13} \mathrm{C}_{3}\right] \mathrm{L}$-serine (Cambridge Isotope Laboratories, CLM-1574-H)

- $500 \mu \mathrm{M}\left[{ }^{13} \mathrm{C}_{6}\right]$ anthranilate (Sigma-Aldrich,709,530)

- $500 \mu \mathrm{M}\left[{ }^{15} \mathrm{~N}_{1}\right]$ indole (Cambridge Isotope Laboratories, NLM-792)

- $500 \mu \mathrm{M}\left[{ }^{13} \mathrm{C}_{8},{ }^{15} \mathrm{~N}_{1}\right]$ indole (Cambridge Isotope Laboratories, CNLM-4786-0)

\section{Homogenization and extraction}

Plant tissue samples, typically $20-50 \mathrm{mg}$, are homogenized for 4 min using a bead mill with three stainless steel balls and $40-100 \mu \mathrm{L}$ of the extraction buffer/solvent.

- Tissue homogenizer (Retsch MM300)

- Microcentrifuge, temperature controlled at $4{ }^{\circ} \mathrm{C}$

- Repeater pipette (Eppendorf M4)
- Homogenization buffer: 65\% isopropanol, 35\% $0.2 \mathrm{M}$ imidazole ( $\mathrm{pH}$ 7.0), $100 \mathrm{mM}$ methoxyamine hydrochloride $\left(\mathrm{CH}_{3} \mathrm{ONH}_{2} \cdot \mathrm{HCl}\right)$ (Sigma-Aldrich, 226,904) for targeted analysis of IAA and biosynthesis intermediates (see Note 3); $50 \%$ isopropanol for analysis of unknown indolic compounds

- For absolute quantitation, stable isotope internal standard is added into homogenization buffer. The amount of internal standard added to each sample should be similar to the amount of endogenous compound in the plant tissue (see Notes 4 and 5)

- Stainless steel beads for homogenization $(1.6 \mathrm{~mm}$ diameter, Next Advance, SSB16)

- $2 \mathrm{~mL}$ screwcap tubes (Fisherbrand, 02-681-343)

- 10-200 $\mu \mathrm{L}$ Empty TopTips (Glygen, TT2EMT) and adaptors provided by Glygen for centrifugation

- Vacuum concentrator (SpeedVac, Savant)

- Additional materials required for specified extraction techniques are described in the sections below:

\section{IAA extraction}

Homogenized samples are incubated on ice for $50 \mathrm{~min}$ to allow isotopic standard equilibration with the endogenous IAA. They are then diluted tenfold with water such that ion exchange will be effective, centrifuged to remove solid materials, and loaded onto two consecutive SPE micro spin column (TopTips) steps, first ion exchange on an amino phase and then on an epoxide support.

- Bondesil- $\mathrm{NH}_{2}$ resin (Agilent, 12,213,020) suspended in water, 1:4 w:v

Table 2 Labeling precursors used for different applications. Example labeling strategies employing different stable isotope-labeled precursors for studying IAA biosynthesis. These strategies can be used in combination with various inhibitors (Table 1) for targeted analysis of specific routes of IAA biosynthesis

\begin{tabular}{|c|c|c|}
\hline Labeled precursor treatment & Germination Media & Purpose/Description \\
\hline $3 \mathrm{mM}\left[{ }^{13} \mathrm{C}_{3}\right]$ Serine & {$\left[{ }^{14} \mathrm{~N}\right]$ ATS } & $\begin{array}{l}\text { Traces synthesis of Trp and Trp-dependent pathway intermediates. } \\
{\left[{ }^{13} C_{3}\right] \text { Serine is condensed with indole to give }\left[{ }^{13} C_{3}\right] \operatorname{Trp}\left(\left[{ }^{13} C_{3}\right] \text {-label is }\right.} \\
\text { incorporated into Trp sidechain) }\end{array}$ \\
\hline $500 \mu \mathrm{M}\left[{ }^{13} \mathrm{C}_{6}\right]$ anthranilate and $500 \mu \mathrm{M}\left[{ }^{15} \mathrm{~N}_{1}\right]$ indole & {$\left[{ }^{14} \mathrm{~N}\right]$ ATS } & $\begin{array}{l}\text { Multiple auxin precursors upstream of Trp are applied to monitor label } \\
\text { incorporation into various intermediates through multiple pathways }\end{array}$ \\
\hline $500 \mu \mathrm{M}\left[{ }^{13} \mathrm{C}_{8}{ }^{15} \mathrm{~N}_{1}\right]$ indole and $500 \mu \mathrm{M}\left[{ }^{15} \mathrm{~N}_{1}\right]$ indole & {$\left[{ }^{14} \mathrm{~N}\right]$ ATS } & $\begin{array}{l}\text { Multiple labeled forms of indole are applied to label indole-derived } \\
\text { metabolites and potential IAA biosynthesis intermediates. LC-MS/ } \\
\text { MS analysis workflow for identifying candidate compounds is } \\
\text { described in the Materials LC-MS analysis section }\end{array}$ \\
\hline $500 \mu \mathrm{M}\left[{ }^{13} \mathrm{C}_{6}\right]$ anthranilate and $500 \mu \mathrm{M}\left[{ }^{13} \mathrm{C}_{8}{ }^{15} \mathrm{~N}_{1}\right]$ indole & {$\left[{ }^{15} \mathrm{~N}\right]$ ATS } & $\begin{array}{l}\text { Growing seedlings on }\left[{ }^{15} \mathrm{~N}\right] \text { ATS media enables rapid }\left[{ }^{15} \mathrm{~N}\right] \text {-labeling of } \\
\text { newly synthesized IAA and biosynthesis intermediates during early } \\
\text { seedling development (Fig. 3) } \\
\text { Unlabeled internal standards may be used for quantitation of IAA } \\
\text { and biosynthetic intermediates in plant tissue grown on }\left[{ }^{15} \mathrm{~N}\right] \text { ATS } \\
\text { (reverse isotope dilution quantitation) }\end{array}$ \\
\hline
\end{tabular}




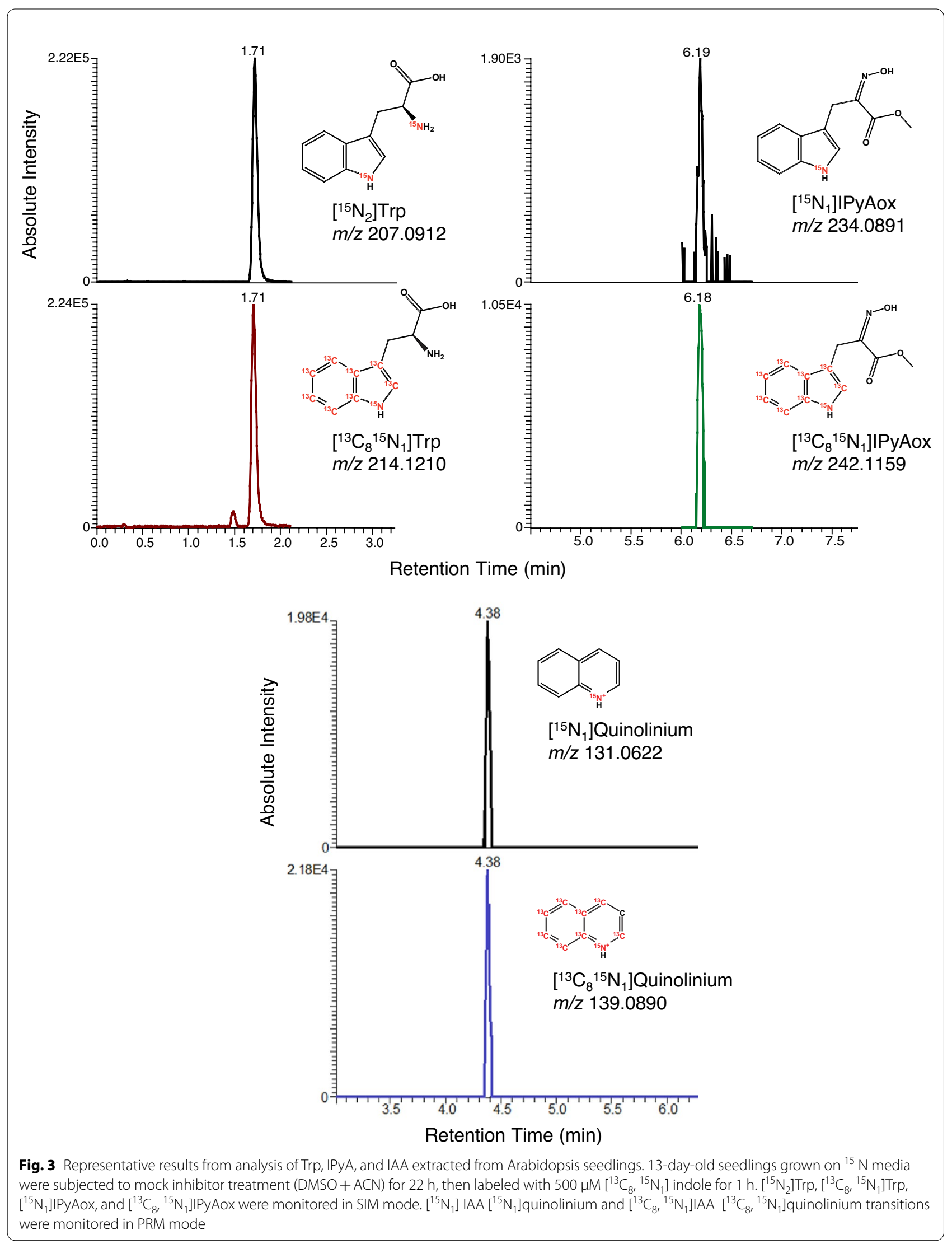


- IAA extraction solvents and solutions as described by Liu et al. [26]: hexane, acetonitrile, ethyl acetate, methanol, 0.2 M imidazole ( $\mathrm{pH} 7.0$ ), distilled water, $0.25 \%$ phosphoric acid (PA), $0.1 \mathrm{M}$ succinic acid (SA, pH 6.0), 5:1 PA:SA solution

- Macro-prep epoxide support resin (Bio-Rad, 156$0000)$, suspended in $0.1 \mathrm{M}$ sodium bicarbonate $(\mathrm{pH}$ 7.0), 1:4 w:v

\section{Extraction of proposed IAA biosynthesis intermediates: Anthranilate, Ser, IAAId, IPyA, IAOx, IAN, IAM, indole} Homogenized samples are incubated on ice for $50 \mathrm{~min}$ utes to allow isotopic standard equilibration with the endogenous compounds, diluted 10-fold with water to allow proper interaction with the solid phase, centrifuged to remove solids, and loaded onto a SPE micro spin column (TopTips) containing hydrophilic-lipophilic balanced (HLB) resin conditioned with acetonitrile followed by $20 \%$ acetonitrile in water. After loading, the spin columns are washed with $5 \%$ acetonitrile and compounds are eluted with $80 \%$ acetonitrile.

- RENSA HLB resin (MIP Technologies, 92,0010010) suspended in methanol, $1: 5 \mathrm{w}: \mathrm{V}$

- Acetonitrile: $100 \%, 80 \%, 20 \%$, and 5\% prepared in distilled water

\section{Indole extraction}

Indole is a very lipophilic and somewhat volatile compound that cannot be purified using the techniques used for the other compounds. Thus, its purification involves a simple solvent partitioning. It was important to select an apolar solvent with a boiling point below the melting point of indole. We found pentane to be well-suited as its boiling point is $36.0^{\circ} \mathrm{C}$, well below the indole melting point of $52.5{ }^{\circ} \mathrm{C}$.

- Pentane

\section{LC-MS analysis}

UPLC utilizes a column with an end-capped octadecylsilane fully porous $1.8 \mu \mathrm{m}$ silica resin with high carbon loading $(20 \%)$ in order to obtain highest sensitivity for indolic compounds (see Additional file 2).

- Amber autosampler vials (ChromTech, 404,810) with $50 \mu \mathrm{L}$ glass inserts (ChromTech, CTI-2405)

- Liquid chromatograph/mass spectrometer system: Dionex UltiMate 3000 UHPLC, Q Exactive mass spectrometer, Xcalibur software (Thermo Scientific)
- $\mathrm{C}_{18}$ HPLC column, $50 \times 2.1 \mathrm{~mm}$ (Force, 9,634,252, Restek) with $0.2 \mu \mathrm{m}$ precolumn filter (UltraShield, 25,809, Restek)

- Mobile phase: A, $0.1 \%$ formic acid in water; B, 0.1\% formic acid in acetonitrile. Different LC-MS methods are used to target compounds of interest:

- IAA analysis: Mobile phase gradient of $5 \% \mathrm{~B}$ (-1-0 min), 5-20\% B (0-3 min), 20-80\% B (3-6 $\mathrm{min}), 80 \% \mathrm{~B}(6-6.5 \mathrm{~min})$ at a flow rate of $0.4 \mathrm{~mL} \cdot \mathrm{min}^{-1}$. Mass spectra are collected in positive ion mode in a parallel reaction monitoring (PRM) scan and the inclusion list contains ions of $176,177,178$, and $182 \mathrm{~m} / z$. PRM resolution is 17500 full width at half maximum (FWHM), automatic gain control (AGC) target is $2 \times 10^{5}$, maximum ionization time is $50 \mathrm{~ms}(\mathrm{~ms})$, isolation window is $2.0 \mathrm{~m} / z$, and normalized collision energy (NCE) is 20. Ion source conditions are: spray voltage: $4.00 \mathrm{kV}$, capillary temperature: $275{ }^{\circ} \mathrm{C}$, probe heater temperature: $300{ }^{\circ} \mathrm{C}$, sheath gas: 30 arbitrary units, aux gas: 20 arbitrary units, S-lens RF level: 50 .

For analysis of all the listed intermediates except indole, inject $5-10 \mu \mathrm{L}$ plant extract into the $\mathrm{LC}$ system with the following mobile phase gradient: $5 \%$ B ( $-2-1 \mathrm{~min}), 5-15 \%$ B (1-3 min), $15-30 \%$ B (3-3.5 min), 30\% B (3.5-5 min), 30-39\% B (5-7.5 min), $39-80 \%$ B (7.5-8 min), $80 \%$ B $(8-8.5 \mathrm{~min})$ at a flow rate of $0.4 \mathrm{~mL} \cdot \mathrm{min}^{-1}$. Mass spectra are collected in selected ion monitoring (SIM) mode. SIM resolution is 70,000 FWHM with maximum ionization time of $200 \mathrm{~ms}$ and AGC of $5 \times 10^{5}$. Ion source conditions are: spray voltage: $4.00 \mathrm{kV}$, capillary temperature: $275^{\circ} \mathrm{C}$, probe heater temperature: $300{ }^{\circ} \mathrm{C}$, sheath gas: 30 arbitrary units, aux gas: 20 arbitrary units, S-lens RF level: 50. MS is set to acquire several segments of full scans each targeting 1-3 compounds. The segments are: $200-217 \mathrm{~m} / z$ $(0-2.1 \mathrm{~min}), \quad 157-173 \mathrm{~m} / z \quad(2.1-3 \mathrm{~min})$, $133-150 \mathrm{~m} / z \quad(3-3.74 \mathrm{~min}), \quad 170-188 \mathrm{~m} / z$ (3.74-5.4 $\mathrm{min}), \quad 152-170 \mathrm{~m} / z \quad(5.4-6 \mathrm{~min})$, $227-245 \mathrm{~m} / z$ (6-6.7 $\mathrm{min}), 184-201 \mathrm{~m} / z(6.7-$ $8.5 \mathrm{~min})$.

For indole analysis, $5-10 \mu \mathrm{L}$ plant extract is injected with the following LC mobile phase gradient: $5 \%$ B ( $-1-1 \mathrm{~min}), 5-30 \%$ B (1-3 $\mathrm{min})$, $30-39 \%$ B (3-5.5 min), 39-80\% B (5.5-6.5 min), $80 \% \mathrm{~B}(6.5-7 \mathrm{~min})$ at a flow rate of $0.4 \mathrm{~mL} \cdot \mathrm{min}^{-1}$. Mass spectra are collected in SIM mode using a 
mass range of $110-132 \mathrm{~m} / z$. SIM resolution is 70,000 FWHM with maximum ionization time of $200 \mathrm{~ms}$ and AGC of $5 \times 10^{5}$. Ion source conditions are: spray voltage: $4.00 \mathrm{kV}$, capillary temperature: $275{ }^{\circ} \mathrm{C}$, probe heater temperature: $300{ }^{\circ} \mathrm{C}$, sheath gas: 30 arbitrary units, aux gas: 20 arbitrary units, S-lens RF level: 50.

For analysis of compounds labeled by treatment with $\left[{ }^{15} \mathrm{~N}_{1}\right]$ - and $\left[{ }^{13} \mathrm{C}_{8},{ }^{15} \mathrm{~N}_{1}\right]$ indole, multiple injections of the same sample are made using a series of methods (A-D, described below) with different MS parameters. The same mobile phase gradient is used with each method: $5 \%$ B (- 2-2 min), 5-50\% B (2-8 min), 50-85\% B $(8-10 \mathrm{~min}), 80 \% \mathrm{~B}(10-12 \mathrm{~min})$ at a flow rate of $0.4 \mathrm{~mL} \cdot \mathrm{min}^{-1}$.

- Method A: Scan groups consist of one full MSSIM scan followed by four PRM scans. For the SIM scan, Orbitrap resolution is 70,000 full width at half maximum (FWHM) with maximum ionization time of $200 \mathrm{~ms}$, automatic gain control (AGC) target of $5 \times 10^{5}$, and scan range of $100-400 \mathrm{~m} / z$. For the PRM scans, FWHM resolution is set to 17,500 , maximum ionization time is $100 \mathrm{~ms}$, AGC target is $2 \times 10^{5}$, normalized collision energy (NCE) is 35 , and isolation window is $20 \mathrm{~m} / z$. Four variations of this method (used in four separate injections) with different values in the inclusion list are used to cover a range of $\mathrm{m} / z$ values for potential compounds of interest:

Method A.1: The inclusion list contains $m / z$ values beginning at 130 and increasing by increments of 20 to $290(130,150,170, \ldots 250,270,290 \mathrm{~m} / z)$

A.2: $\mathrm{m} / z$ values begin at 140 and increase by increments of 20 to 300

A.3: $\mathrm{m} / z$ values begin at 300 and increase by increments of 20 to 460

A.4: $m / z$ values begin at 310 and increase by increments of 20 to 470

- Method B: LC-MS parameters are nearly identical to Method A, except that the isolation window is changed to $2 \mathrm{~m} / z$ and the inclusion list is designed to cover a $20 \mathrm{~m} / z$ range with values increasing by increments of $2 \mathrm{~m} / z$. The inclusion list is customized to target features of interest observed using Method A. For example, to investigate a candidate peak identified in the $210 \mathrm{~m} / z$ scan filter from Method A, the inclusion list for Method B would contain 200, 202, $204, \ldots 216,218,220 \mathrm{~m} / z$.
- Method C: Again, LC-MS parameters are nearly identical to Methods A and B, except that the isolation window is further narrowed to $1 \mathrm{~m} / z$ and the inclusion list is customized to isolate the isotopomers of interest observed with Method B. Values within $1-2 \mathrm{~m} / z$ of the scan range containing features of interest found from Method B are included. For example, to target a peak observed in the $206 \mathrm{~m} / z$ scan filter from Method B, 205, 206, and $207 \mathrm{~m} / z$ should be added to the inclusion list of Method C.

- Method D: Scan groups include one full MS- SIM scan followed by one PRM scan. MS parameters are the same as those described above except that the NCE is 15 and the isolation window is $\leq 1 \mathrm{~m} / z$. The inclusion list is customized to contain only the $\left[{ }^{13} \mathrm{C}_{8}\right.$, $\left.{ }^{15} \mathrm{~N}_{1}\right]-$, $\left[{ }^{15} \mathrm{~N}_{1}\right]$-, and unlabeled molecular ions of interest with as much specificity as possible.

\section{Methods \\ Growing seedlings with inhibitor and stable isotope precursor treatments}

Seedlings are grown in vitro on mesh squares, allowing them to be easily transferred to chemical inhibitor treatments at the desired timepoints. A liquid solution containing stable isotope-labeled precursors is then supplied to seedlings, and synthesis of isotopically labeled IAA and intermediates can be identified and distinguished by LC-HR-MS.

1. In a laminar flow hood, moisten sterile nylon mesh squares with sterile water and use forceps to place squares flat on germination media (see Note 7 and Table 2) in square Petri dishes.

2. Clean Arabidopsis seeds by shaking in $20 \%$ bleach solution for $5 \mathrm{~min}$ and rinsing 4 times with sterile water.

3. Sow seeds approximately $0.5 \mathrm{~cm}$ apart in single row on mesh.

4. Store plates at $4 \mathrm{C}$ in the dark for 3-7 days to stratify seeds. Remove plates from cold and place vertically in growth conditions.

5. Transfer seedlings onto inhibitor media (Table 1) to begin auxin biosynthesis inhibition treatment (see Note 8). In a laminar flow hood, use forceps to gently lift mesh with seedlings from germination plates and lay flat onto plates containing inhibitor media. Cover plates and place vertically under growth conditions.

6. Begin isotopic labeling treatments by flooding plates with $3 \mathrm{~mL}$ of labeling solution (Table 2). Gently rock plate back and forth 5-10 times to 
ensure labeling solution covers entire mesh square. Cover plates and place flat under growth conditions for 0-24 h (see Note 8).

7. Collect samples by gathering $10-50 \mathrm{mg}$ of plant tissue (see Notes 9 and 10), gently blotting away moisture on a KimWipe, and placing in a microcentrifuge tube. Immediately submerge tube in liquid nitrogen to flash freeze and place on dry ice. Store samples at $-80 \mathrm{C}$ until extraction.

8. Holding frozen samples on dry ice, add $20 \mu \mathrm{L}$ of homogenization solution per $10 \mathrm{mg}$ tissue and $2-3$ beads to each sample.

9. Homogenize samples in tissue homogenizer for $4 \mathrm{~min}$ at $1500 \mathrm{RPM}$ and incubate samples on ice for $1 \mathrm{~h}$ (see Note 11 )

10. Add $90 \mu \mathrm{L}$ of water to each homogenized sample per $10 \mu \mathrm{L}$ homogenization buffer and shake tube to mix.

11. Centrifuge samples at $25,000 \mathrm{~g}$ for $10 \mathrm{~min}$. at $4{ }^{\circ} \mathrm{C}$.

12. Prepare samples for LC-MS analysis using purification methods specified for compounds of interest:

\section{Indole}

Indole is a biosynthetic precursor of IAA and Trp, and is extracted by solvent partitioning.

13. Transfer $200 \mu \mathrm{L}$ supernatant into a new tube. Add $100 \mu \mathrm{L}$ pentane and vortex at room temperature for $5 \mathrm{~min}$.

14. Spin samples a short time to clearly separate the organic and aqueous phases. Transfer the upper organic layer into a new tube. Save the aqueous phase for extraction of IAA (steps 16-21) or auxin biosynthesis intermediates (steps 22-26).

15. Evaporate pentane with vacuum concentrator and resuspend sample in $20 \mu \mathrm{L}$ acetonitrile

\section{IAA}

IAA is typically present at low levels in plant tissues and can be extracted separately from other compounds using more selective methods for optimal detection. IAA samples are purified by solid phase extraction (SPE) using an amino $\left(\mathrm{NH}_{2}\right)$ resin followed by a second step with polymethylmethacrylate epoxide (PMME) resin.

16. Prepare TopTips with $\mathrm{NH}_{2}$ resin for SPE according to Liu et al. [26]. Add $20 \mu \mathrm{L}$ resin suspension per TopTip; wash with $50 \mu \mathrm{L}$ each: hexane, acetonitrile, ethyl acetate; condition with $50 \mu \mathrm{L} 0.2 \mathrm{M}$ imidazole followed by $2 \times 100 \mu \mathrm{L}$ water
17. Load supernatant from step 11 onto prepared TopTips. For larger samples, $250 \mu \mathrm{L}$ of supernatant can be loaded at a time and spun through. Reload and spin until all supernatant has been loaded. Wash with $50 \mu \mathrm{L}$ methanol.

18. Exchange tubes under TopTip adapters to fresh $2 \mathrm{~mL}$ tubes for elution. Elute with $3 \times 50 \mu \mathrm{L}$ of PA, then add $25 \mu \mathrm{L}$ of SA to each sample.

19. Prepare TopTips with PMME resin for solid phase extraction (SPE) according to Liu et al. (2012). Add $75 \mu \mathrm{L}$ PMME resin suspension per TopTip; wash with $2 \times 100 \mu \mathrm{L}$ methanol; condition with $2 \times 100$ $\mu \mathrm{L}$ PA:SA.

20. Load samples onto prepared TopTips. Wash with 2 $\times 50 \mu \mathrm{L}$ PA:SA.

21. Exchange tubes under TopTip adapters to clean $1.5 \mathrm{~mL}$ tubes for elution. Elute with $2 \times 50 \mu \mathrm{L}$ methanol. Reduce volume of each sample to approximately $20 \mu \mathrm{L}$ with vacuum concentrator.

\section{Proposed IAA biosynthesis pathway intermediates: Anthranilate, Ser, IPyA, IAAId, IAOx, IAN, IAM}

Samples are prepared for analysis of biosynthesis intermediates by SPE using an HLB resin. SPE is an effective sample preparation technique for these compounds because it provides a high level of recovery and is relatively easy to use with large sample sets. IAA can also be extracted using the following method, but with some loss of sensitivity compared to methods described in the previous section.

22. Prepare TopTips with HLB resin for SPE. Add 25 $\mu \mathrm{L}$ resin suspension per TopTip; equilibrate with 2 $\times 50 \mu \mathrm{L} 100 \%$ acetonitrile and $2 \times 50 \mu \mathrm{L} 20 \%$ acetonitrile.

23. Load supernatant onto prepared TopTips.

24. If highly sensitive detection and quantification of IAA is required, save $200-300 \mu \mathrm{L}$ of supernatant for separate IAA analysis (steps 16-21). IAA may be extracted and analyzed simultaneously with precursor compounds if samples contain sufficiently high IAA levels (typically $\geq 2 \mathrm{ng}$ ).

25. Wash with $50 \mu \mathrm{L} 5 \%$ acetonitrile.

26. Exchange tubes under TopTip adapters to clean $1.5 \mathrm{~mL}$ tubes for elution. Elute with $2 \times 50 \mu \mathrm{L} 80 \%$ acetonitrile. Reduce volume of each sample to approximately $20 \mu \mathrm{L}$ using vacuum concentrator (about 10-12 min). 


\section{Unknown indolic compounds (double indole labeling samples)}

An unbiased extraction method is used for discovery of unknown compounds synthesized from indole.

27. Transfer supernatant to a clean tube and centrifuge again at $25,000 \mathrm{~g}$ for $10 \mathrm{~min}$. at $4{ }^{\circ} \mathrm{C}$ to remove all debris.

\section{LC-MS analysis}

Samples are analyzed using LC-HRAM-MS to chromatographically separate components of chemical matrix and obtain high resolution $\mathrm{m} / z$ data. Specific LC-MS methods are tailored for different sample types and analysis objectives (see method details in "Materials" section).

28. Carefully transfer each sample to a $50 \mu \mathrm{L}$ glass insert so that no air pockets remain at the bottom of the insert. Assemble insert into autosampler vial with cap.

29. Inject $5-10 \mu \mathrm{L}$ of sample for $\mathrm{LC}-\mathrm{MS}$ analysis using methods described in the LC-MS analysis subsection of the Materials section.

\section{Data analysis}

IAA analysis Extracted ion chromatograms (EICs) of labeled and unlabeled quinolinium ions generated by fragmentation of labeled internal standard and unlabeled endogenous IAA are viewed (see Additional file 2). Narrow mass ranges are used to filter out background noise.

30. Under the "Ranges" tab in "Chromatogram Ranges" in Xcalibur, set the chromatogram viewing options to display two mass ranges: 130.0641-130.0661 (corresponding to unlabeled quinolinium ion), and 136.0843-136.0863 ( $\left[{ }^{13} \mathrm{C}_{6}\right]$ quinolinium produced from $\left[{ }^{13} \mathrm{C}_{6}\right]$ IAA internal standard). Under "Display" tab, check "Peak Area." Use "peak selection" tool to select and calculate area of peaks corresponding to unlabeled IAA and the internal standard. Endogenous IAA levels can be calculated using isotope dilution $[25,39]$.

Targeted IAA precursor analysis Peak areas from EICs of multiple compounds are determined using a script. Mass ranges surrounding the exact masses of ions produced from the compounds of interest, as well as their labeled forms synthesized from the supplied labeled precursors, are kept within a narrow window to exclude background noise.
31. Raw data files are converted to mzXML format using the msconvert tool from the ProteoWizzard software [40] prior to input into R. Quantitative data for each indolic compound is extracted using the Metabolite-Turnover script developed in the Hegeman lab (https://github.com/Hegem anLab/Metabolite-Turnover, [41]). In this script, the ProteinTurnover [42] and the XCMS package [43] are employed to extract EICs for each isotopmer of IAA and intermediates. This quantification approach using linear regression [44] is preferred over that using peak area [39] when the MS data has high background noise due to low analyte abundance.

32. Exact masses for isotopomers of interest are calculated using the University of Wisconsin-Madison Biological Magnetic Resonance Data Bank exact mass calculator (http://www.bmrb.wisc.edu/metab olomics/mol_mass.php). Isotopomers of proposed IAA biosynthetic intermediates derived from several isotopic labeling strategies are listed in Table 3. (See Note 12)

33. In the data output csv files, the slope of each linear regression line represents the ratio of the respective isotopic trace to its monoisotopmer. This ratio is used to calculate the relative abundance of labeled compounds, allowing us to track label incorporation from upstream precursors into IAA intermediates through multiple pathways.

Double indole labeling data analysis Supplying plants two differentially labeled form of indole provides a way to identify indole-derived compounds, as downstream intermediates will incorporate both labels. These samples are analyzed in a series of LC-MS/MS injections, initially scanning broadly for formation of labeled quinolinium ions, and then narrowing in on precise ions in subsequent injections until a molecular ion can be identified and fragmented to provide further structural information.

34. Use LC-MS method A1 (described in Materials section "LC-MS analysis") to identify potential features producing $\left[{ }^{15} \mathrm{~N}_{1}\right]$ - and $\left[{ }^{13} \mathrm{C}_{8},{ }^{15} \mathrm{~N}_{1}\right]$ quinolinium ions.

a. Under the "Ranges" tab in "Chromatogram Ranges" in Xcalibur, set the chromatogram viewing options to display three mass ranges: 130.0641-130.0661 (corresponding to unlabeled quinolinium ion), 131.0612-131.0632 ([ $\left.{ }^{15} \mathrm{~N}_{1}\right]$ quinolinium), and $139.0880-139.0900\left(\left[{ }^{13} \mathrm{C}_{8},{ }^{15} \mathrm{~N}_{1}\right]\right.$ quinolinium). 
Table 3 The $m / z$ values of isotopomers measured in the IAA and intermediates analyses

\begin{tabular}{|c|c|c|c|c|c|c|}
\hline & $\mathrm{M}(+\mathrm{H})$ & ${ }^{15} \mathrm{~N}_{1}$ & ${ }^{13} C_{1}$ & ${ }^{15} \mathrm{~N}_{2}$ & ${ }^{13} \mathrm{C}_{1}{ }^{15} \mathrm{~N}_{1}$ & ${ }^{13} \mathrm{C}_{1}{ }^{15} \mathrm{~N}_{2}$ \\
\hline ANT & 138.0550 & 139.0520 & 139.0583 & & 140.0553 & \\
\hline IND & 118.0651 & 119.0622 & 119.0685 & & 120.0655 & \\
\hline Trp & 205.0972 & 206.0942 & 206.1005 & 207.0912 & & \\
\hline Ser & 106.0499 & 107.0469 & 107.0532 & & & \\
\hline TAM & 161.1073 & 162.1044 & 162.1107 & 163.1014 & 163.1077 & 164.1047 \\
\hline IAOx & 175.0866 & 176.0836 & 176.0899 & 177.0807 & 177.0870 & 178.0840 \\
\hline IAM & 175.0866 & 176.0836 & 176.0899 & 177.0807 & 177.0870 & 178.0840 \\
\hline IAN & 157.0760 & 158.0731 & 158.0794 & 159.0701 & & 160.0734 \\
\hline IPyAox & 233.0921 & 234.0891 & 234.0954 & & 235.0925 & \\
\hline IAAldox & 189.1022 & 190.0993 & 190.1056 & & 191.1026 & \\
\hline IAA & 176.0706 & 177.0676 & 177.0740 & & 178.0710 & \\
\hline \multirow{2}{*}{ Quinolinium } & 130.0651 & 131.0622 & 131.0685 & & & \\
\hline & ${ }^{2} \mathrm{H}_{4}$ & ${ }^{13} C_{6}$ & ${ }^{13} \mathrm{C}_{6}{ }^{15} \mathrm{~N}_{1}$ & ${ }^{13} C_{7}$ & ${ }^{13} \mathrm{C}_{7}{ }^{15} \mathrm{~N}_{1}$ & ${ }^{13} \mathrm{C}_{8}{ }^{15} \mathrm{~N}_{1}$ \\
\hline ANT & & 144.0751 & 145.0721 & 145.0784 & & 147.0788 \\
\hline IND & & 124.0853 & 125.0823 & 125.0886 & & 127.0890 \\
\hline Trp & & 211.1173 & 212.1143 & & 213.1177 & 214.1210 \\
\hline \multicolumn{7}{|l|}{ Ser } \\
\hline TAM & & & 168.1245 & & 169.1278 & 170.1312 \\
\hline IAOx & & & 182.1038 & & 183.1071 & 184.1105 \\
\hline IAM & & & 182.1038 & & 183.1071 & 184.1105 \\
\hline IAN & & & 164.0932 & & 165.0965 & 166.0999 \\
\hline IPyAox & & 239.1122 & 240.1092 & 240.1156 & & 242.1159 \\
\hline IAAldox & & 195.1224 & 196.1194 & 196.1257 & & 198.1261 \\
\hline IAA & 180.0957 & 182.0907 & 183.0878 & 183.0941 & & 185.0945 \\
\hline Quinolinium & 134.0902 & 136.0853 & & & & 139.0890 \\
\hline
\end{tabular}

b. Set "Scan Filter" to display chromatogram from the first ion of the inclusion list. Note any coeluting peaks present in both the $\left[{ }^{15} \mathrm{~N}_{1}\right]$ quinolinium and $\left[{ }^{13} \mathrm{C}_{8},{ }^{15} \mathrm{~N}_{1}\right]$ quinolinium mass ranges. Ions producing these peaks may have incorporated label from the indole treatments.

c. View chromatograms through each Scan Filter, keeping the same mass ranges specified above, and continue to note any candidate peaks with matching retention times.

35. Repeat workflow described in step 33 with method A2 to identify additional candidate features.

36. Perform subsequent injection with method B, aiming to narrow $\mathrm{m} / \mathrm{z}$ windows containing the parent ions. View data using the same settings in Xcalibur that were used in step 33, taking note of retention times and scan windows that show the presence of coeluting peaks for both quinolinium labeled mass ranges.

37. Perform subsequent injection with method $C$ to progress toward pinpointing molecular ions. This method should be tailored to candidate peaks that were identified in steps $33-35$.

a. Using the same mass ranges settings to target quinolinium ion isotopomers, view EIC through each scan filter to identify the filter range containing the strongest quinolinium signal. The molecular ion is expected to be near (within $1 \mathrm{~m} / z$ ) this value.

38. Customize method $\mathrm{D}$ to include approximate molecular ion values identified in step 35 in the inclusion list. Run sample using this method to obtain exact mass spectra.

39. Compare spectra produced from each of the three ions in the inclusion list of method $\mathrm{D}$, taking note of exact mass differences between the major ions of different spectra. Exact mass differences of 0.9970 , 9.0239 , and $8.0268 \mathrm{~m} / z$ correspond to the differences between ${ }^{15} \mathrm{~N}_{1}$ and unlabeled, ${ }^{13} \mathrm{C}_{8}{ }^{15} \mathrm{~N}_{1}$ and unlabeled, and ${ }^{13} \mathrm{C}_{8}{ }^{15} \mathrm{~N}_{1}$ and ${ }^{15} \mathrm{~N}_{1}$, respectively. 
40. If no molecular ions are observed, NCE settings in method D can be set to a lower intensity to preserve a greater abundance of molecular ion.

41. Unlabeled molecular ion and spectral data can be searched against mass spectral databases to identify potential compound identities: MassBank, METLIN, NIST Tandem Mass Spectral Library, m/ zCloud, MS-DIAL.

42. Confirm compound identities by comparing retention time and mass spectral data against authentic standards.

\section{Notes}

$1500 \mu \mathrm{M}\left[{ }^{13} \mathrm{C}_{11},{ }^{15} \mathrm{~N}_{2}\right] \operatorname{Trp}$ (or other labeled forms of Trp) may also be used as a labeled precursor treatment [5, 12, 14, 31, 45]; however, results should be examined cautiously as high levels of exogenous Trp will feedback inhibit anthranilate synthase and anthranilate phosphoribosyltransferase [46-48], which may confound results.

2 To improve solubility, labeled indole can first be dissolved in a small volume of acetonitrile; anthranilate can first be dissolved in a small volume of isopropanol. Labeled indole and anthranilate concentrations were based on observation that significant labeling of IAA and biosynthetic precursors was achieved after incubation with $500 \mu \mathrm{M}$ labeled precursor for $16 \mathrm{~h}$, and labeled Ser concentrations were chosen to approximate endogenous Ser levels [49]. However, concentrations may be adjusted as needed for use in other systems (see Table 4).

3 IPyA and IAAld degrade quickly and need to be derivatized with $\mathrm{CH}_{3} \mathrm{ONH}_{2}$ to generate their oximes (IPyA-MeOx and IAAld-MeOx). Standards should be derivatized and freshly prepared.

4. For IAA quantitation by isotope dilution, mix $10 \mathrm{ng}$ of stable isotope labeled-IAA per $1 \mathrm{~mL}$ homogenization buffer. We recommend using $\left[{ }^{13} \mathrm{C}_{6}\right]$ IAA (Cam-

Table 4 Common problems and troubleshooting guide. Adapted from Liu et al. [26]

\begin{tabular}{|c|c|c|}
\hline Problem & Possible reasons & Solutions \\
\hline $\begin{array}{l}\text { Liquid does not pass through TopTips before loading } \\
\text { plant samples }\end{array}$ & The slit on TopTips is too narrow & $\begin{array}{l}\text { Increase the centrifugal force to make liquid pass } \\
\text { through, or switch to a new TopTip }\end{array}$ \\
\hline $\begin{array}{l}\text { Liquid does not pass through TopTips after loading } \\
\text { plant samples }\end{array}$ & Plant debris blocks the TopTip slit & $\begin{array}{l}\text { Always try to avoid transferring plant debris into } \\
\text { TopTips } \\
\text { Increase the centrifugal force to make liquid pass } \\
\text { through } \\
\text { Use a dissecting probe to remove visible plant debris }\end{array}$ \\
\hline \multirow[t]{3}{*}{ Drift of LC retention time } & Injection volume is too large & $\begin{array}{l}\text { Evaporate eluate or extract to a smaller volume with } \\
\text { vacuum concentrator } \\
\text { Reduce the sample volume injected onto the LC }\end{array}$ \\
\hline & Change of LC mobile phase & $\begin{array}{l}\text { Check that correct, freshly prepared mobile phase } \\
\text { solvents are being used } \\
\text { Purge the LC lines after changing solvents }\end{array}$ \\
\hline & LC solvents are blocked or leaking & $\begin{array}{l}\text { Replace the precolumn filter } \\
\text { Check column connections and reinstall if needed } \\
\text { Check LC lines for leaking solvent }\end{array}$ \\
\hline \multirow{2}{*}{$\begin{array}{l}\text { Low yield of labeled compounds, but normal yield } \\
\text { of endogenous compounds and/or internal } \\
\text { standards }\end{array}$} & Slow turnover & Increase the labeling time period \\
\hline & Insufficient intake of labeled precursors & $\begin{array}{l}\text { Increase the concentration of labeled precursors in the } \\
\text { labeling solution } \\
\text { Make sure plants are bathed in sufficient volume of } \\
\text { labeling solution }\end{array}$ \\
\hline \multirow[t]{3}{*}{ Broad/tailed LC peaks } & Injection volume is too large & $\begin{array}{l}\text { Evaporate eluate or extract to a lower volume with } \\
\text { vacuum concentrator } \\
\text { Reduce the sample volume injected onto the LC }\end{array}$ \\
\hline & The precolumn filter is dirty & Replace the filter \\
\hline & The column is dirty & $\begin{array}{l}\text { Disconnect the LC line from the MS source and wash } \\
\text { the column with solvent according to manufacturer's } \\
\text { instructions }\end{array}$ \\
\hline Analyte $m / z$ values do not match calculated values & The MS needs to be calibrated & $\begin{array}{l}\text { Perform mass calibration with calibration standard } \\
\text { mixture according to instrument manual }\end{array}$ \\
\hline \multirow[t]{2}{*}{ Reduced MS sensitivity } & The MS needs to be calibrated & See above \\
\hline & The tune file needs to be modified & $\begin{array}{l}\text { Adjust source parameters for optimal ion intensity } \\
\text { using standard compounds }\end{array}$ \\
\hline
\end{tabular}


bridge Isotope Laboratories, CLM-1896) in experiments where other $\left[{ }^{13} \mathrm{C}_{6}\right]$-labeled precursors (such as $\left[{ }^{13} \mathrm{C}_{6}\right]$ anthranilate) are not used.

5 For reverse isotope dilution quantitation, use unlabeled internal standards as endogenous compounds are $\left[{ }^{15} \mathrm{~N}\right]$-labeled in plants germinated on $\left[{ }^{15} \mathrm{~N}\right]$ ATS media. Add $50 \mathrm{nM}$ ANT, $500 \mathrm{nM}$ indole, $5 \mu \mathrm{M}$ Trp, 1 nM IAM, $2.5 \mu$ M IAN, 100 nM IPyA, $10 \mathrm{nM}$ IAAld, 10 nM IAA, 1 nM TAM, 10 nM IAOx and $100 \mathrm{mM}$ freshly prepared methoxylamine hydrochloride $\left(\mathrm{CH}_{3} \mathrm{ONH}_{2} \cdot \mathrm{HCl}\right)$ into homogenization buffer. In the data analysis output for reverse isotope dilution samples, the slope of each linear regression line represents the ratio of the respective isotopic trace (labeled compounds) to its monoisotopomer (unlabeled internal standard added) and is used to quantify the isotopic traces.

6 Although MS parameters are altered in subsequent injections, it is important to keep the LC gradient consistent with method A so that retention times are consistent across injections.

7 For absolute quantitation of compounds by reverse isotope dilution, use fully $\left[{ }^{15} \mathrm{~N}\right]$-labeled salts in both germination and inhibitor media. If only relative label incorporation data is needed, unlabeled media can be used.

8 Timing for inhibitor treatments, isotopic labeling, and sample collection can be adapted to study auxin biosynthesis at different developmental stages. Significant IAA biosynthesis inhibition can be observed in 12-day seedlings (grown under 10/14-h photoperiod, cool white fluorescent lights at $\sim 100 \mu \mathrm{mol} \mathrm{m} \mathrm{m}^{-2} \mathrm{~s}^{-1}$ at $22{ }^{\circ} \mathrm{C}$ ) after $20 \mathrm{~h}$ on $100 \mu \mathrm{M}$ YDF and $30 \mu \mathrm{M}$ PVM2153 media with 30 min labeling treatment. Under these conditions, we observed greater label incorporation into IAA from labeled indole compared to other precursors. Endogenous levels of IAA precursors such as Trp may increase in the presence of biosynthesis inhibitors [20].

9 For absolute quantitation, record fresh weight of harvested tissues. This data is later used for isotope dilution calculations.

10 Recommended amounts for tissue collection: 40-50 mg per sample for $\left[{ }^{13} C_{3}\right]$ serine labeling or double indole labeling; $10-30 \mathrm{mg}$ for indole/anthranilate labeling experiments. More tissue may be needed depending on plant tissue type and inhibitor treatment

11 Plant tissue should be completely pulverized after homogenization. If significant plant material remains intact, repeat homogenization step.

12 We recommend using a mass range window of the calculated $m / z$ value \pm 0.003 .

\section{Supplementary Information}

The online version contains supplementary material available at https://doi. org/10.1186/s13007-021-00763-0.

Additional file 1: $\left[{ }^{15} \mathrm{~N}_{1}\right]$ Indole, $\left[{ }^{2} \mathrm{H}_{5}\right]$ tryptophan, and $\left[{ }^{13} \mathrm{C}_{6}\right]$ anthranilate labeling of IAA precursors in Arabidopsis hypocotyls in the presence of YDF.

Additional Figure 2: Extracted lon Chromatogram (EIC) of targeted metabolites.

\section{Acknowledgements}

Not applicable

\section{Authors' contributions}

QT and MT developed the methods and wrote the protocol; MT, QT, and JDC wrote the article; JDC supervised the method development. All authors read and approved the final manuscript.

\section{Funding}

Funding was provided by Agriculture and Food Research Initiative competitive awards no. 2018-67011-28056, 2018-67013-27503 and 2019-51181-30025 from the USDA National Institute of Food and Agriculture, NSF Plant Genome Research Program grant IOS-1238812, the Minnesota Agricultural Experiment Station, and by the Gordon and Margaret Bailey Endowment for Environmental Horticulture.

Availability of data and materials

The data generated in the present study are available from the corresponding author upon reasonable request.

\section{Declarations}

Ethics approval and consent to participate

Not applicable.

\section{Consent for publication}

Not applicable.

\section{Competing interests}

The authors declare no competing interests.

Received: 13 February 2021 Accepted: 7 June 2021

Published online: 22 June 2021

\section{References}

1. Tivendale ND, Ross JJ, Cohen JD. The shifting paradigms of auxin biosynthesis. Trends Plant Sci. 2014;19(1):44-51.

2. Cooke TJ, Poli D, Sztein AE, Cohen JD. Evolutionary patterns in auxin action. In: Perrot-Rechenmann C, Hagen G, editors. Auxin Molecular Biology. New York: Springer; 2002. p. 319-38.

3. Woodward AW, Bartel B. Auxin: Regulation, action, and interaction. Ann Bot. 2005;95(5):707-35.

4. Tivendale ND, Cohen JD. Analytical history of auxin. J Plant Growth Regul. 2015;34(4):708-22

5. Mashiguchi K, Tanaka K, Sakai T, Sugawara S, Kawaide H, Natsume M, Hanada A, Yaeno T, Shirasu K, Yao H. The main auxin biosynthesis pathway in Arabidopsis. Proc Natl Acad Sci. 2011;108(45):18512-7.

6. Sugawara S, Hishiyama S, Jikumaru Y, Hanada A, Nishimura T, Koshiba T, Zhao Y, Kamiya Y, Kasahara H. Biochemical analyses of indole-3-acetaldoxime-dependent auxin biosynthesis in Arabidopsis. Proc Natl Acad Sci. 2009;106(13):5430-5

7. Nonhebel H, Yuan Y, Al-Amier H, Pieck M, Akor E, Ahamed A, Cohen JD, Celenza JL, Normanly J. Redirection of tryptophan metabolism in tobacco by ectopic expression of an Arabidopsis indolic glucosinolate biosynthetic gene. Phytochemistry. 2011;72(1):37-48. 
8. Rajagopal R. Metabolism of indole-3-acetaldehyde. III. Some charac teristics of the aldehyde oxidase of Avena coleoptiles. Physiol Plant. $1971 ; 24(2): 272-81$.

9. Tsurusaki K, Takeda K, Sakurai N. Conversion of indole-3-acetaldehyde to indole-3-acetic acid in cell-wall fraction of barley (Hordeum vulgare) seedlings. Plant Cell Physiol. 1997;38(3):268-73.

10. Koshiba T, Matsuyama H. An in vitro system of indole-3-acetic acid formation from tryptophan in maize (Zea mays) coleoptile extracts. Plant Physiol. 1993;102(4):1319-24.

11. Quittenden LJ, Davies NW, Smith JA, Molesworth PP, Tivendale ND, Ross JJ. Auxin biosynthesis in pea: characterization of the tryptamine pathway. Plant Physiol. 2009;151(3):1130-8.

12. Wright AD, Sampson MB, Neuffer MG, Michalczuk L, Slovin JP, Cohen JD. Indole-3-acetic acid biosynthesis in the mutant maize orange pericarp, a tryptophan auxotroph. Science. 1991;254(5034):998-1000.

13. Normanly J, Cohen JD, Fink GR. Arabidopsis thaliana auxotrophs reveal a tryptophan-independent biosynthetic pathway for indole-3-acetic acid. Proc Natl Acad Sci. 1993;90(21):10355-9.

14. Östin A, llić N, Cohen JD. An in vitro system from maize seedlings for tryptophan-independent indole-3-acetic acid biosynthesis. Plant Physiol. 1999;119(1):173-8.

15. Nonhebel HM. Tryptophan-independent indole-3-acetic acid synthesis: Critical evaluation of the evidence. Plant Physiol. 2015;169(2):1001-5.

16. Cheng Y, Dai X, Zhao Y. Auxin synthesized by the YUCCA flavin monooxygenases is essential for embryogenesis and leaf formation in Arabidopsis. Plant Cell. 2007;19(8):2430-9.

17. Fukui K, Hayashi K. Manipulation and sensing of auxin metabolism, transport and signaling. Plant Cell Physiol. 2018;59(8):1500-10.

18. Cheng Y, Dai X, Zhao Y. Auxin biosynthesis by the YUCCA flavin monooxygenases controls the formation of floral organs and vascular tissues in Arabidopsis. Genes Dev. 2006;20(13):1790-9.

19. Pieck M, Yuan Y, Godfrey J, Fisher C, Zolj S, Vaughan D, Thomas N, Wu C, Ramos J, Lee N. Auxin and tryptophan homeostasis are facilitated by the ISS1NAS1 aromatic aminotransferase in Arabidopsis. Genetics. 2015;201(1):185-99.

20. NarukawaNara M, Nakamura A, Kikuzato K, Kakei Y, Sato A, Mitani Y, YamasakiKokudo Y, Ishii T, Hayashi K, Asami T. Aminooxy-naphthylpropionic acid and its derivatives are inhibitors of auxin biosynthesis targeting L-tryptophan aminotransferase: structure-activity relationships. Plant J. 2016;87(3):245-57.

21. Kriechbaumer $V$, Weigang L, Fießelmann A, Letzel T, Frey M, Gierl A, Glawischnig E. Characterisation of the tryptophan synthase alpha subunit in maize. BMC Plant Biol. 2008;8(1):44.

22. Zhang R, Wang B, Ouyang J, Li J, Wang Y. Arabidopsis indole synthase, a homolog of tryptophan synthase alpha, is an enzyme involved in the trpindependent indole-containing metabolite biosynthesis. J Integr Plant Biol. 2008;50(9):1070-7.

23. Watkins-Dulaney E, Straathof S, Arnold F. Tryptophan synthase: biocatalyst extraordinaire. ChemBioChem. 2021;22(1):5-16.

24. Wright AD, Moehlenkamp CA, Perrot GH, Neuffer MG, Cone KC. The maize auxotrophic mutant orange pericarp is defective in duplicate genes for tryptophan synthase beta. Plant Cell. 1992;4(6):711-9.

25. Barkawi LS, Tam Y-Y, Tillman JA, Normanly J, Cohen JD. A highthroughput method for the quantitative analysis of auxins. Nat Protoc. 2010;5(10):1609-18.

26. Liu X, Hegeman AD, Gardner G, Cohen JD. Protocol: high-throughput and quantitative assays of auxin and auxin precursors from minute tissue samples. Plant Methods. 2012;8(1):1-17.

27. Ljung K, Hull AK, Celenza J, Yamada M, Estelle M, Normanly J, Sandberg G. Sites and regulation of auxin biosynthesis in Arabidopsis roots. Plant Cell. 2005;17(4):1090-104.

28. Barkawi LS, Tam Y-Y, Tillman JA, Pederson B, Calio J, Al-Amier H, Emerick M, Normanly J, Cohen JD. A high-throughput method for the quantitative analysis of indole-3-acetic acid and other auxins from plant tissue. Anal Biochem. 2008;372(2):177-88.

29. Novák O, Hényková E, Sairanen I, Kowalczyk M, Pospišil T, Ljung K. Tissuespecific profiling of the Arabidopsis thaliana auxin metabolome. Plant J. 2012;72(3):523-36.

30. Epstein E, Cohen JD, Slovin JP. The biosynthetic pathway for indole-3-acetic acid changes during tomato fruit development. Plant Growth Regul. 2002:38(1):15-20.
31. Rapparini F, Cohen JD, Slovin JP. Indole-3-acetic acid biosynthesis in Lemna gibba studied using stable isotope labeled anthranilate and tryptophan. Plant Growth Regul. 1999;27(3):139-44.

32. Rapparini F, Tam YY, Cohen JD, Slovin JP. Indole-3-acetic acid metabolism in Lemna gibba undergoes dynamic changes in response to growth temperature. Plant Physiol. 2002;128(4):1410-6.

33. Erdmann N, Schiewer U. Tryptophan-dependent indoleacetic-acid biosynthesis from indole, demonstrated by double-labelling experiments. Planta. 1971:97(2):135-41.

34. Soeno K, Sato A, Shimada Y. Investigation of Auxin Biosynthesis and Action Using Auxin Biosynthesis Inhibitors. In: Hicks GR, Robert S, editors. Plant Chemical Genomics. New York: Springer; 2021. p. 131-44.

35. Bloch $\mathrm{K}$, Anker H. An extension of the isotope dilution method. Science. 1948;107:228.

36. Yu P, Hegeman AD, Cohen JD. A facile means for the identification of indolic compounds from plant tissues. Plant J. 2014;79(6):1065-75.

37. Tang Q, Yu P, Tillmann M, Cohen JD, Slovin JP. Indole-3-acetylaspartate and indole-3-acetylglutamate, the IAA-amide conjugates in the diploid strawberry achene, are hydrolyzed in growing seedlings. Planta. 2019:249(4):1073-85.

38. Lincoln C, Britton JH, Estelle M. Growth and development of the axr 1 mutants of Arabidopsis. Plant Cell. 1990;2(11):1071-80.

39. Cohen JD, Baldi BG, Slovin JP. ${ }^{13} \mathrm{C}_{6}$-[Benzene Ring]-indole-3-acetic acid: a new internal standard for quantitative mass spectral analysis of indole3-acetic acid in plants. Plant Physiol. 1986;80(1):14-9.

40. Chambers MC, Maclean B, Burke R, Amodei D, Ruderman DL, Neumann S, Gatto L, Fischer B, Pratt B, Egertson J. A cross-platform toolkit for mass spectrometry and proteomics. Nat Biotechnol. 2012;30(10):918-20.

41. Evans EM, Freund DM, Sondervan VM, Cohen JD, Hegeman AD. Metabolic patterns in Spirodela polyrhiza revealed by ${ }^{15} \mathrm{~N}$ stable isotope labeling of amino acids in photoautotrophic, heterotrophic, and mixotrophic growth conditions. Front Chem. 2018;6:191.

42. Fan K-T, Rendahl AK, Chen W-P, Freund DM, Gray WM, Cohen JD, Hegeman AD. Proteome scale-protein turnover analysis using high resolution mass spectrometric data from stable-isotope labeled plants. J Proteome Res. 2016;15(3):851-67.

43. Smith CA, Want EJ, O'Maille G, Abagyan R, Siuzdak G. XCMS: processing mass spectrometry data for metabolite profiling using nonlinear peak alignment, matching, and identification. Anal Chem. 2006;78(3):779-87.

44. Huttlin EL, Hegeman AD, Harms AC, Sussman MR. Comparison of full versus partial metabolic labeling for quantitative proteomics analysis in Arabidopsis thaliana. Mol Cell Proteomics. 2007;6(5):860-81.

45. Baldi BG, Maher BR, Slovin JP, Cohen JD. Stable isotope labeling, in vivo, of $\mathrm{D}$-and L-tryptophan pools in Lemna gibba and the low incorporation of label into indole-3-acetic acid. Plant Physiol. 1991;95(4):1203-8.

46. Sugimoto S, Shiio I. Regulation of tryptophan biosynthesis by feedback inhibition of the second-step enzyme, anthranilate phosphoribosyltransferase Brevibacterium flavum. Agric Biol Chem. 1983;47(10):2295-305

47. Poulsen C, Bongaerts RJ, Verpoorte R. Purification and characterization of anthranilate synthase from Catharanthus roseus. Eur J Biochem. 1993:212(2):431-40

48. Niyogi KK, Fink GR. Two anthranilate synthase genes in Arabidopsis: defense-related regulation of the tryptophan pathway. Plant Cell. 1992;4(6):721-33.

49. Riens B, Lohaus G, Heineke D, Heldt HW. Amino acid and sucrose content determined in the cytosolic, chloroplastic, and vacuolar compartments and in the phloem sap of spinach leaves. Plant Physiol. 1991;97(1):227-33.

50. Kakei Y, Yamazaki C, Suzuki M, Nakamura A, Sato A, Ishida Y, Kikuchi R, Higashi S, Kokudo Y, Ishii T. Small-molecule auxin inhibitors that target YUCCA are powerful tools for studying auxin function. Plant J. 2015;84(4):827-37.

51. Zhu Y, Li H, Su Q, Wen J, Wang Y, Song W, Xie Y, He W, Yang Z, Jiang K. A phenotype-directed chemical screen identifies ponalrestat as an inhibitor of the plant flavin monooxygenase YUCCA in auxin biosynthesis. J Biol Chem. 2019;294(52):19923-33.

52. Nishimura T, Hayashi K, Suzuki H, Gyohda A, Takaoka C, Sakaguchi $Y$, Matsumoto S, Kasahara H, Sakai T, Kato J. Yucasin is a potent inhibitor of YUCCA, a key enzyme in auxin biosynthesis. Plant J. 2014;77(3):352-66.

53. Tsugafune S, Mashiguchi K, Fukui K, Takebayashi Y, Nishimura T, Sakai T, Shimada Y, Kasahara H, Koshiba T, Hayashi K. Yucasin DF, a potent and persistent inhibitor of auxin biosynthesis in plants. Sci Rep. 2017;7(1):13992. 
54. He W, Brumos J, Li H, Ji Y, Ke M, Gong X, Zeng Q, Li W, Zhang X, An F. A small-molecule screen identifies L-kynurenine as a competitive inhibitor of TAA1/TAR activity in ethylene-directed auxin biosynthesis and root growth in Arabidopsis. Plant Cell. 2011;23(11):3944-60.

55. Soeno K, Goda H, Ishii T, Ogura T, Tachikawa T, Sasaki E, Yoshida S, Fujioka S, Asami T, Shimada Y. Auxin biosynthesis inhibitors, identified by a genomics-based approach, provide insights into auxin biosynthesis. Plant Cell Physiol. 2010;51(4):524-36.

56. Matchett WH. Inhibition of tryptophan synthetase by indoleacrylic acid. J Bacteriol. 1972;110(1):146-54.

57. Marabotti A, Cozzini P, Mozzarelli A. Novel allosteric effectors of the tryptophan synthase a2 $\beta 2$ complex identified by computer-assisted molecular modeling. Biochimica et Biophysica Acta (BBA)-Protein Structure and Molecular Enzymology. 2000;1476(2):287-99.

58. Xu Y, Abeles RH. Inhibition of tryptophan synthase by (1-fluorovinyl) glycine. Biochem. 1993;32(3):806-11.

59. Finn J, Langevine C, Birk I, Birk J, Nickerson K, Rodaway S. Rational herbicide design by inhibition of tryptophan biosynthesis. Bioorganic Med Chem Lett. 1999;9(16):2297-302

60. Dias MVB, Canduri F, da Silveira NJF, Czekster CM, Basso LA, Palma MS, Santos DS, de Azevedo WF. Molecular models of tryptophan synthase from Mycobacterium tuberculosis complexed with inhibitors. Cell Biochem Biophys. 2006;44(3):375-84.
61. Abrahams KA, Cox JA, Fütterer K, Rullas J, Ortega-Muro F, Loman NJ, Moynihan PJ, Pérez-Herrán E, Jiménez E, Esquivias J. Inhibiting mycobacterial tryptophan synthase by targeting the inter-subunit interface. Sci Rep. 2017;7(1):1-15.

62. Michalska K, Chang C, Maltseva NI, Jedrzejczak R, Robertson GT, Gusovsky F, McCarren P, Schreiber SL, Nag PP, Joachimiak A. Allosteric inhibitors of Mycobacterium tuberculosis tryptophan synthase. Protein Sci. 2020;29(3):779-88.

63. Ngo H, Harris R, Kimmich N, Casino P, Niks D, Blumenstein L, Barends TR, Kulik V, Weyand M, Schlichting I. Synthesis and characterization of allosteric probes of substrate channeling in the tryptophan synthase bienzyme complex. Biochem. 2007;46(26):7713-27.

64. Naz S, Farooq U, Ali S, Sarwar R, Khan S, Abagyan R. Identification of new benzamide inhibitor against a-subunit of tryptophan synthase from Mycobacterium tuberculosis through structure-based virtual screening, anti-tuberculosis activity and molecular dynamics simulations. J Biomol Struct Dyn. 2019;37(4):1043-53.

\section{Publisher's Note}

Springer Nature remains neutral with regard to jurisdictional claims in published maps and institutional affiliations.
Ready to submit your research? Choose BMC and benefit from:

- fast, convenient online submission

- thorough peer review by experienced researchers in your field

- rapid publication on acceptance

- support for research data, including large and complex data types

- gold Open Access which fosters wider collaboration and increased citations

- maximum visibility for your research: over 100M website views per year

At BMC, research is always in progress.

Learn more biomedcentral.com/submissions 